\title{
DAMPAK PERTAMBANGAN NIKEL PT.IFISHDECO TERHADAP KONDISI LINGKUNGAN HIDUP DI DESA RORAYA KECAMATAN TINANGGEA KABUPATEN KONAWE SELATAN
}

\author{
Septianto Aldiansyah ${ }^{1}$, La Ode Nursalam² \\ ${ }^{1}$ Alumni Jurusan Pendidikan Geografi FKIP UHO \\ ${ }^{2}$ Dosen Jurusan Pendidikan Geografi FKIP UHO \\ ${ }^{1}$ Email : septiantoaldiansyah863@gmail.com
}

\begin{abstract}
Abstrak: Rumusan masalah dalam penelitian ini (1) Bagaimana dampak yang ditimbulkan oleh aktifitas pertambangan nikel PT.Ifishdeco terhadap kondisi lingkungan hidup di Desa Roraya Kecamatan Tinanggea Kabupaten Konawe Selatan? (2) Bagaimana kerusakan lingkungan yang ditimbulkan oleh aktifitas pertambangan nikel PT.Ifishdeco terhadap kondisi lingkungan hidup di Desa Roraya Kecamatan Tinanggea Kabupaten Konawe Selatan?. Penelitian ini menggunakan metode deskriptif kualitatif dengan pendekatan mix metode. Hasil penelitian menunjukan bahwa dampak positif kegiatan pertambangan nikel, seperti: bertambahnya PAD dari sektor pertambangan, terciptanya lapangan pekerjaan, terbukanya wilayah dari keterisolasian. Dampak negatif : 1) Kerusakan jalan 60,7\%; 2) Pencemaran sungai, kali, rawa 78,6\%; 3) Polusi udara 64,3\%; 4) Terganggunya lahan pertanian 92,9\%; 5) Terganggu/mengurangi areal perkebunan $75 \%$; 6) Penurunan produktifitas pertanian/perkebunan 78,6\%; 7) Kerusakan flora 89,3\% dan fauna 71,4\%; 8) Tidak adanya pemberdayaan kesehatan $75 \%$ dan tidak adanya peningkatan prasarana kesehatan $57,1 \%$; 9) Perubahan perilaku/norma masyarakat $64,3 \%$.
\end{abstract}

Kata Kunci :Dampak, pertambangan nikel, dampak positif, dampak negatif. 


\title{
IMPACT OF PT. IFISHDECO NICKEL MINING TO ENVIRONMENTAL CONDITIONS IN RORAYA VILLAGE TINANGGEA DISTRICT SOUTH KONAWE REGENCY
}

\author{
Septianto Aldiansyah ${ }^{1}$, La Ode Nursalam ${ }^{2}$ \\ ${ }^{1}$ Alumni Of Geography Education FKIP UHO \\ ${ }^{2}$ Lecturer Of Geography Education FKIP UHO \\ ${ }^{1}$ Email : septiantoaldiansyah863@gmail.com
}

\begin{abstract}
Problem formulation in this research are (1) What is the influence caused by PT. Fishdeco's field activities to environmental conditions in Roraya Village, Tinanggea District, South Konawe Regency? (2) What is the environmental damage caused by PT. Fishdeco's activities to the environmental conditions in Roraya Village, Tinanggea District, South Konawe Regency? This research uses descriptive qualitative method with mixed survey method. The results showed that activities were positive, such as: increasing PAD from the government sector, creating jobs, opening up areas of isolation. Negative impact: 1) Road damage 60.7\%; 2) River, swamp pollution $78.6 \%$; 3) Air pollution $64.3 \%$; 4) Disruption of agricultural land 92.9\%; 5) Interrupted/reduced plantation area $75 \%$; 6) Decreasing agricultural/plantation productivity $78.6 \%$; 7) Flora damage $89.3 \%$ and fauna $71.4 \%$; 8 ) There is no $75 \%$ health empowerment and no $57.1 \%$ health improvement; 9) Changes in community behavior / norms $64.3 \%$.
\end{abstract}

Keywords: Impact, nickel mining, positive impact, negative impact

\section{PENDAHULUAN}

Di Indonesia Kegiatan pengelolaan kekayaan alam beberapa tahun terakhir ini banyak dilaksanakan pada sumberdaya mineral dan bijih-bijih, hal ini terbukti dengan adanya berbagai industri pertambangan seperti nikel, emas, batu bara, mangan, besi, minyak bumi, gas bumi dan lain-lain. Pengelolaan sumberdaya mineral oleh industri pertambangan khususnya bagi daerah dilakukan karena dipandang dapat memberikan Pendapatan Asli Daerah (PAD) yang lebih tinggi sehingga dapat meningkatkan perekonomian dan pembangunan negara, serta terciptanya lapangan pekerjaan bagi masyarakat lokal maupun masyarakat di luar lokasi pertambangan.

Provinsi Sulawesi Tenggara merupakan wilayah yang cukup kaya dengan sumber daya alamnya, potensi sumber daya alam yang sudah dikelola secara besar-besaran adalah potensi pertambangan nikel (BPS Sultra, 2011). Sulawesi Tenggara banyak terdapat bahan tambang dari berbagai jenis batuan, baik batuan beku, batuan sedimen, dan batuan metamorf. Salah satu jenis batuan yang berpotensi dijadikan bahan tambang nikel adalah batuan laterit. Batuan laterit adalah hasil pelapukan batuan ultrabasa baik dari jenis peridotit yang berupa tanah yang mengandung endapan biji besi atau besinikel (fe-Ni).

Kegiatan pertambangan yang dilakukan oleh PT.Ifishdeco sangat merugikan lingkungan warga di Desa Roraya. Mengutip dari redaksi Kolakaposnews bahwa akibat aktifitas perusahaan penambang nikel tersebut, persawahan warga di beberapa desa di 
Kecamatan Tinanggea khususnya Desa Roraya tercemar lumpur hingga pertumbuhan padi terhambat dan sering mengalami gagal panen. Daerah aliran sungai (DAS) Roraya yang dahulu mengalir dengan lancar, sekarang telah tercemar dan dipenuhi dengan endapan lumpur. Saluran air mengalami penyempitan karena lumpur aktifitas penambangan. DAS yang menjadi sumber air bersih bagi warga menjadi tercemar. Air menjadi keruh dan tidak bisa di komsumsi. Setiap musim hujan berkepanjangan sungai Roraya meluap mengakibatkan sawah para petani tenggelam sehingga produksi padi semakin berkurang akibat dampaknya.

Melihat kenyataan tersebut mendorong peneliti untuk mengetahui seberapa jauh kerusakan lingkungan terjadi melalui penelitian dengan Judul : Dampak Penambangan Nikel PT. Ifishdeco Terhadap Kondisi Lingkungan Hidup Desa Roraya Kecamatan Tinanggea Kabupaten Konawe Selatan.

Menurut Rissamasu (2010: 54) mengemukakan bahwa munculnya sejumlah persoalan yang mengiringi kegiatan usaha pertambangan di lapangan diantaranya: 1) Terkorbankannya pemilik lahan.; 2) Kerusakan lingkungan; 3) Ketimpangan sosial. Di lain pihak, kegiatan usaha pertambangan membawa pendatang dengan tingkat pendidikan cukup, menerapkan teknologi menengah sampai tinggi, dengan budaya dan kebiasaan yang terkadang bertolak belakang dengan masyarakat setempat. Kondisi ini menyebabkan munculnya kesenjangan sosial antara lingkungan pertambangan dengan masyarakat di sekitar usaha pertambangan berlangsung.

$$
\text { Menurut Dewi }
$$

lingkungan adalah jumlah semua benda hidup dan mati serta seluruh kondisi yang ada di dalam lingkungan dan ruang yang kita tempati.
Menurut Undang - Undang Republik Indonesia No. 32 Tahun 2009 tentang Perlindungan dan Pengelolaan Lingkungan Hidup maka lingkungan hidup adalah suatu kesatuan ruang dengan semua benda, daya, keadaan, dan makhluk hidup, termaksud manusia dan perilakunya, yang mempengaruhi alam itu sendiri, kelangsungan perkehidupan, dan kesejahteraan manusia serta makhluk hidup lain.

Pelestarian lingkungan hidup adalah rangkain upaya untuk melindungi kemampuan lingkungan hidup terhadap tekanan, perubahan, dan dampak negatif yang ditimbulkan oleh suatu kegiatan agar tetap mempu mendukung kehidupan manusia dan makhluk hidup lainnya (Kuswardoyo, 2009:194).

\section{METODE PENELITIAN}

\section{Jenis Penelitian}

Jenis penelitian ini bersifat deskriptif kualitatif. Hasil penelitian ini lebih difokuskan agar dapat memberikan gambaran sebenarnya dari obyek yang akan diteliti, yaitu dampak pertambangan nikel PT. Ifishdeco terhadap kondisi lingkungan hidup Desa Roraya Kecamatan Tinanggea Kabupaten Konawe Selatan.

\section{Waktu dan Tempat Penelitian}

Penelitian ini dilaksanakan pada bulan Maret 2018 yang bertempat di Desa Roraya, Kecamatan Tinanggea, Kabupaten Konawe Selatan.

\section{Informan Penelitian}

Penentuan informan penelitian menggunakan teknik purposive sampling yaitu teknik penentuan sampel dengan pertimbangan atau kriteria-kriteria tertentu. Informan berjumlah 28 orang 
yang terdiri dari 1 orang kepala desa, 4 orang kepala dusun dan 23 orang masyarakat yang terdiri dari Petani, PNS, dan Wiraswasta.

\section{Instrumen Penilaian}

1. Daftar pertanyaan yang menjadi pedoman wawancara kepada responden yaitu Kepala desa dan masyarakatnya.

2. Kamera dan alat perekam sebagai alat dokumentasi.

\section{Jenis Data dan Sumber Data}

Jenis data yang digunakan dalam penelitian ini adalah data primer dan data sekunder. Data primer adalah data yang diperoleh peneliti secara langsung (dari tangan pertama). Data sekunder adalah sumber data penelitian yang diperoleh peneliti secara tidak langsung melalui media perantara (diperoleh dan dicatat oleh pihak lain).

\section{Teknik Pengumpulan Data}

Teknik pengumpulan data yang digunakan: a. Observasi (pengamatan dan pencatatan sistematik atas unsurunsur suatu objek penelitian); $b$. Dokumentasi; c. Wawancara (tanya jawab antar subjek dan objek yang diteliti), jenis wawancara yang dilakukan adalah wawancara terstruktur.

\section{Tehnik Analisis Data}

Data yang telah dikumpulkan dalan penelitian di analisis secara deskriptif kualitatif. Tahapan analisis data deskriptif kualitatif sebagai berikut: 1) Menelaah seluruh data yang tersedia dari berbagai sumber, yaitu wawancara, angket, pengamatan yang sudah dituliskan dalam catatatn lapangan, dokumen pribadi, dokumen resmi, gambar foto dan sebagainya; 2) Mereduksi data, memilih hal-hal yang pokok, menfokuskan pada hal-hal yang penting, dicari tema dan polanya dan membuang yang tidak perlu; 3) Penarikan kesimpulan, penyederhanaan tanpa mengurangi isi data penelitian; 4) Kesimpulan atau verifikasi. Teknik analisis data dalam penelitian ini menggunakan rumus:

$P=\frac{F}{N} \times 100 \%$

Keterangan :

$\mathrm{P}=$ Kategori (persentase pilihan)

$\mathrm{F}=$ Frekuensi (jumlah responden yang memilih alternatif yang sama)

$\mathrm{N}=$ Jumlah responden keseluruhan

$100=$ Persentase $(\%)$

\section{GAMBARAN UMUM}

\section{Gambaran Umum Lokasi Penelitian}

1. Gambaran Umum Tentang Pertambangan Nikel PT.Ifishdeco

Secara geografis, letak pertambangan nikel di desa Roraya memiliki batas-batas wilayah:

a. Sebelah Utara berbatasan dengan Desa Wundumbolo

b. Sebelah Selatan berbatasan dengan Desa Persiapan Roraya Utama

c. Sebelah Barat berbatasan dengan Kali/Desa Lanowulu

d. Sebelah Timur berbatasan dengan Desa Telutu Jaya

2. Identitas Informan

a) Jenis Kelamin Informan

Informan penelitian yang berada di wilayah pertambangan berjumlah 28 orang yang terdiri dari 20 laki-laki dan 8 perempuan.

b) Umur Informan

Umur informan yaitu 31-40 tahun yaitu 9 orang dan 41-50 tahun 9 orang, usia 20-30 tahun yakni 7 orang dan 51-60 tahun 3 orang.

c) Tingkat Pendidikan Informan Tingkat pendidikan informan SMA sederajat dan SD sederajat sebanyak 9 orang, SMA sederajat sebanyak 9 
orang, SMP sederajat sebanyak 6 orang, Tingkat Perguruan Tinggi sebanyak 4 orang,.

d) Pekerjaan Informan

Pekerjaan informan adalah Petani 13 orang, Wiraswasta 12 orang, dan PNS 3 orang.

\section{Sejarah Singkat PT.Ifishdeco}

Ifishdeco merupakan anak perusahaan PT. Sekar Alam yang berpusat di Surabaya. PT Sekar Alam kemudian membuka perkebunan jambu mete di Konawe Selatan dengan bendera PT. Ifishdeco. Akan tetapi produksi perkebunan jambu tersebut kurang maksimal karena tanahnya kritis dan mengandung nikel. Sehingga yang awalnya PT Ifishdeco adalah perusahaan pengelola jambu kini menjadi Perusahaan pengelolah bijih nikel.

\section{HASIL PENELITIAN}

\section{A. Dampak dan Kerusakan Lingkungan} Pemahaman Masyarakat Tentang
Kegiatan Pertambangan Nikel di Desa
Roraya dapat Menimbulkan Dampak
Lingkungan

Untuk mengetahui bagaimana pengetahuan informasi mengenai tanggapan masyarakat tentang dampak lingkungan kegiatan pertambangan, maka diajukan pertanyaan: "Apakah Bapak/ibu mengetahui bahwa setiap kegiatan pertambangan pasti akan menimbulkan dampak lingkungan?" Pengetahuan informan tentang dampak lingkungan dari kegiatan pertambangan dapat dilihat pada tabel 4.1.

Tabel4.1. Pengetahuan masyarakat tentang kegiatan pertambangan nikel di Desa Roraya menimbulkan dampak lingkungan

\begin{tabular}{clcc}
\hline \multirow{2}{*}{ No } & $\begin{array}{l}\text { Pengetahuan tentang pertambangan nikel } \\
\text { menimbulkan dampak lingkungan }\end{array}$ & $\begin{array}{c}\text { Frekuensi } \\
(\mathbf{F})\end{array}$ & $\begin{array}{c}\text { Persentase } \\
\left(\frac{F}{N} \mathbf{x} \mathbf{1 0 0 \%}\right)\end{array}$ \\
\hline \multirow{2}{*}{1} & Tahu & 25 & 89,3 \\
\cline { 2 - 5 } & Tidak tahu $\quad$ Total $(\mathbf{N})$ & 3 & 10,7 \\
\hline & & $\mathbf{2 8}$ & $\mathbf{1 0 0 \%}$ \\
\hline
\end{tabular}

Sumber: Data Diolah (2018)

Terkait pertanyaan yang diberikan, tabel di atas menunjukan sebanyak 25 informan tahu bahwa kegiatan pertambangan menimbulkan dampak lingkungan. Sementara 3 informan mengatakan tidak tahu. Hal ini menunjukan $89,3 \%$ informan menanggapi hadirnya pertambangan nikel telah menimbulkan perubahan lingkungan fisik baik itu lingkungan alam maupun lingkungan sosial yang bersifat positif. Hadirnya pertambangan nikel juga membuat masyarakat mulai membuka usaha-usaha seperti kios dan warung makan. Selain itu terdapat dampak negatif diberbagai aspek seperti lingkungan biotik diantaranya rusaknya tumbuh-tumbuhan, gangguan kesehatan, selain itu dampak pada lingkungan fisik seperti DAS yang menjadi kotor, lahan persawahan yang terganggu, areal perkebunan yang terganggu dan berkurang serta dampak terhadap lingkungan sosial misalnya terjadinya perubahan prilaku/norma di desa roraya dan sebagainya.

Berdasarkan uraian di atas, dapat disimpulkan pengetahuan masyarakat bahwa kegiatan pertambangan menimbulkan dampak lingkungan dengan banyaknya tanggapan informan yakni $25(89,3 \%)$. 


\section{Pengetahuan masyarakat tentang pertambangan nikel di Desa Roraya telah menimbulkan kerusakan lingkungan}

Untuk mengetahui tingkat pengetahuan masyarakat tentang pertambangan nikel di desa Roraya telah menimbulkan kerusakan lingkungan, maka diajukan pertanyaan: "Apakah Bapak/ibu menilai bahwa kegiatan pertambangan nikel di desa ini telah menimbulkan kerusakan lingkungan?". Pengetahuan informan tentang kerusakan lingkungan dari kegiatan pertambangan dapat dilihat pada tabel 4.2.

Tabel 4.2. Pengetahuan masyarakat tentang kegiatan pertambangan nikel di Desa Roraya telah menimbulkan kerusakan lingkungan

\begin{tabular}{clcc}
\hline \multirow{2}{*}{ No } & $\begin{array}{l}\text { Pengetahuan tentang pertambangan nikel } \\
\text { menimbulkan kerusakan lingkungan }\end{array}$ & $\begin{array}{c}\text { Frekuensi } \\
(\mathbf{F})\end{array}$ & $\begin{array}{c}\text { Persentase } \\
\left(\frac{F}{N} \mathbf{x} \mathbf{1 0 0 \%}\right)\end{array}$ \\
\hline \multirow{2}{*}{2} & Tahu & 25 & 89,3 \\
\cline { 2 - 4 } & Tidak tahu & 3 & 10,7 \\
\hline \multirow{2}{*}{ Total $(\mathbf{N})$} & $\mathbf{2 8}$ & $\mathbf{1 0 0 \%}$ \\
\hline
\end{tabular}

Sumber: Data Diolah (2018)

Terkait dengan pertanyaan yang diberikan, tabel di atas menunjukan sebanyak 25 informan menjawab tahu bahwa kegiatan pertambangan nikel di desa Roraya telah menimbulkan kerusakan lingkungan. Sementara 3 informan menjawab tidak tahu. Hal ini menunjukan $\quad 89,3 \%$ informan menanggapi munculnya berbagai persoalan seperti adanya kerusakan lahan pertanian karena tertimbun endapan lumpur, lahan dengan kondisi kritis dan rusak akibat pengerukan, polusi udara berupa debu serta tercemarnya air sungai/kali yang dapat menjadi merah ketika hujan turun kemudian membawa material aktifitas pengerukan pertambangan ke sungai akibat pencemaran zat kimia tambang.

Berdasarkan uraian di atas, dapat disimpulkan pengetahuan masyarakat

Tabel 4.3. Tanggapan masyarakat tentang pertambangan di Desa Roraya menimbulkan kerusakan jalan

\begin{tabular}{|c|c|c|c|}
\hline No & Tanggapan tentang kerusakan jalan & $\begin{array}{l}\text { Frekuensi } \\
\text { (F) }\end{array}$ & $\begin{array}{l}\text { Persentase } \\
\left(\frac{F}{N} \times 100 \%\right)\end{array}$ \\
\hline \multirow{2}{*}{3} & Menimbulkan kerusakan jalan & 17 & 60,7 \\
\hline & Tidak menimbulkan kerusakan jalan & 11 & 39,3 \\
\hline & Total $(\mathbf{N})$ & 28 & $100 \%$ \\
\hline
\end{tabular}

Sumber: Data Diolah (2018) bahwa kegiatan pertambangan menimbulkan kerusakan lingkungan dengan banyaknya tanggapan informan yakni $25(89,3 \%)$.

\section{B. Dampak terhadap Lingkungan Fisik \\ Tanggapan masyarakat tentang pertambangan di Desa Roraya menimbulkan kerusakan jalan}

Untuk mengetahui tanggapan masyarakat tentang pertambangan nikel di Desa Roraya menimbulkan kerusakan jalan, maka diajukan pertanyaan: "Apakah Bapak/ibu menilai jalan menjadi rusak dengan masuknya pertambangan nikel di desa ini?" Tanggapan informan tentang kerusakan jalan dari kegiatan pertambangan dapat dilihat pada tabel 4.3. 
Terkait dengan pertanyaan yang diajukan, tabel di atas menunjukan sebanyak 17 informan menjawab bahwa kegiatan pertambangan nikel menimbulkan kerusakan jalan. Sementara 11 informan menjawab tidak menimbulkan kerusakan jalan. Hal ini menunjukan $60,7 \%$ informan menanggapi jalan kendaraan alat pengangkut nikel menuju pelabuhan yang memotong jalan poros menjadi berlubang.

Berdasarkan uraian di atas, dapat disimpulkan kegiatan pertambangan nikel di Desa Roraya menimbulkan kerusakan jalan dengan banyaknya tanggapan informan yakni 17 (60,7\%).

\begin{abstract}
Tanggapan masyarakat tentang pertambangan nikel di Desa Roraya menimbulkan pencemaran air (warna dan bau air sumur)

Untuk mengetahui bagaimana tanggapan masyarakat tentang pencemaran air atau air sumur masyarakat menjadi berwarna/berbau pengaruh kegiatan pertambangan nikel di Desa Roraya, maka diajukan pertanyaan: "Apakah air sumur Bapak/ibu berbau/berwarna setelah masuknya pertambangan nikel di desa ini?" Tanggapan informan tentang pencemaran air atau air sumur dari kegiatan pertambangan dapat dilihat pada tabel 4.4.
\end{abstract}

Tabel 4.4. Tanggapan masyarakat tentang pertambangan di Desa Roraya menimbulkan pencemaran air sumur

\begin{tabular}{clcc}
\hline \multirow{2}{*}{ No } & $\begin{array}{l}\text { Tanggapan tentang pencemaran air sumur } \\
\text { (berwarna/berbau) }\end{array}$ & $\begin{array}{c}\text { Frekuensi } \\
(\mathbf{F})\end{array}$ & $\begin{array}{c}\text { Persentase } \\
\left(\frac{F}{N} \mathbf{x} \mathbf{1 0 0 \%}\right)\end{array}$ \\
\hline \multirow{2}{*}{4} & Berbau/berwarna & 7 & 25 \\
\cline { 2 - 4 } & Tidak berbau/berwarna & 21 & 75 \\
\hline Total (N) & $\mathbf{2 8}$ & $\mathbf{1 0 0 \%}$ \\
\hline
\end{tabular}

Sumber: Data Diolah (2018)

Terkait dengan pertanyaan yang diajukan, menunjukan sebanyak 7 informan menjawab bahwa kegiatan pertambangan nikel di Desa Roraya menimbulkan pencemaran air sumur. Sementara 21 informan menjawab tidak. Hal ini menunjukan $25 \%$ informan menanggapi air sumur berwarna kekuning-kuningan dan sedikit kabur disebabkan rembesan air buangan dari tambang dan air sumur yang masih berkontaminasi dengan tanah liat.

Berdasarkan uraian di atas, dapat disimpulkan kegiatan pertambangan nikel di Desa Roraya tidak menimbulkan pencemaran air sumur (berbau/berwarna) dengan banyaknya tanggapan informan yakni $21(75 \%)$.
Tanggapan masyarakat tentang pertambangan nikel menimbulkan pencemaran air sungai/kali pandangan masyarakat tentang pertambangan nikel di Desa Roraya menimbulkan pencemaran air sungai/kali, maka diajukan pertanyaan: "Apakah Bapaklibu menilai air sungai/kali menjadi kotor setelah masuknya pertambangan nikel di desa ini?" Tanggapan informan tentang pencemaran air sungai/kali dari kegiatan pertambangan dapat dilihat pada tabel 4.5. 
Jurnal Penelitian Pendidikan Geografi Volume 4 Nomor 1 Januari 2019

Tabel 4.5. Tanggapan masyarakat tentang pertambangan di Desa Roraya menimbulkan pencemaran air sungai/kali

\begin{tabular}{clccc}
\hline \multirow{2}{*}{ No } & Tanggapan tentang pencemaran air sungai/kali & $\begin{array}{c}\text { Frekuensi } \\
(\mathbf{F})\end{array}$ & $\begin{array}{c}\text { Persentase } \\
\left(\frac{F}{N} \mathbf{x} \mathbf{1 0 0 \%}\right)\end{array}$ \\
\hline \multirow{2}{*}{5} & Tercemar & 22 & 78,6 \\
\cline { 2 - 5 } & Tidak tercemar & 6 & 21,4 \\
\hline & & Total $(\mathbf{N})$ & $\mathbf{2 8}$ & $\mathbf{1 0 0 \%}$ \\
\hline
\end{tabular}

Sumber: Data Diolah (2018)

Terkait pertanyaan yang diajukan, menunjukan sebanyak 22 informan menjawab bahwa kegiatan pertambangan nikel menimbulkan pencemaran air sungai/kali. Sementara 6 informan menjawab tidak. Hal ini menunjukan $\quad 78,6 \%$ informan menanggapi air sungai/kali tercemar karena limbah buangan dan zat-zat kimia yang tercemar di atas permukaan tanah ketika hujan akan dibawa oleh aliran air menuju sungai/kali sehingga air sungai/kali menjadi. Sedang di musim kemarau air sungai akan berlumpur berwarna kuning kecoklat-coklatan pekat.

Berdasarkan uraian di atas, dapat disimpulkan kegiatan pertambangan nikel di Desa Roraya menimbulkan pencemaran air sungai/kali dengan banyaknya tanggapan informan yakni 22 $(78,6 \%)$.

\section{Tanggapan masyarakat tentang adanya pencemara udara berupa debu oleh kegiatan pertambangan nikel di Desa Roraya Untuk mengetahui bagaimana tanggapan masyarakat tentang pertambangan nikel di Desa Roraya menimbulkan adanya pencemaran udara berupa debu, maka diajukan pertanyaan: "Apakah Bapak/ibu merasakan adanya polusi udara berupa debu setelah masuknya pertembangan nikel masuk di desa ini?". Untuk lebih jelasnya mengenai tanggapan informan tentang pencemaran udara dari kegiatan pertambangan dapat dilihat pada tabel 4.6.}

Tabel 4.6. Tanggapan masyarakat tentang pertambangan di Desa Roraya menimbulkan pencemaran/polusi udara

\begin{tabular}{llcc}
\hline No & $\begin{array}{l}\text { Tanggapan tentang pencemaran udara/polusi } \\
\text { udara }\end{array}$ & $\begin{array}{c}\text { Frekuensi } \\
(\mathbf{F})\end{array}$ & $\begin{array}{l}\text { Persentase } \\
\left(\frac{F}{N} \mathbf{x} \mathbf{1 0 0 \%}\right)\end{array}$ \\
\hline \multirow{2}{*}{6} & Merasakan dan terganggu dengan polusi udara & 18 & 64,3 \\
\cline { 2 - 4 } & $\begin{array}{l}\text { Tidak merasakan dan tidak terganggu dengan } \\
\text { polusi udara }\end{array}$ & 10 & 35,7 \\
\hline & \multicolumn{2}{c|}{ Total (N) } & $\mathbf{1 0 0 \%}$ \\
\hline
\end{tabular}

Sumber: Data Diolah (2018)

Terkait dengan pertanyaan yang diajukan, menunjukan sebanyak 18 informan menjawab bahwa kegiatan pertambangan nikel di Desa Roraya menimbulkan pencemaran udara berupa debu. Sementara 10 informan menjawab tidak. Hal ini menunjukkan menunjukan
$64,3 \%$ informan menanggapi mengganggu aktivitas keseharian masyarakat terutama pada saat musim kemarau.

Berdasarkan uraian di atas, dapat disimpulkan kegiatan pertambangan nikel di Desa Roraya menimbulkan 
pencemaran udara/polusi udara dengan banyaknya tanggapan informan yakni 18 $(64,3 \%)$.

Tanggapan masyarakat tentang adanya gangguan dari kebisingan yang ditimbulkan pertambangan nikel di Desa Roraya

Untuk mengetahui bagaimana tanggapan masyarakat tentang adanya gangguan kebisingan dari kegiatan pertambangan nikel di Desa Roraya, maka diajukan pertanyaan: "Apakah Bapak/ibu merasa terganggu dengan bunyi alat berat atau truk-truk pengangkut dari kegiatan pertambangan nikel di desa ini?".Tanggapan informan tentang kebisingan yang ditimbulkan dari kegiatan pertambangan dapat dilihat pada tabel 4.7.

Tabel 4.7. Tanggapan masyarakat tentang adanya gangguan kebisingan dari pertambangan nikel di Desa Roraya

\begin{tabular}{clcc}
\hline \multirow{2}{*}{ No } & $\begin{array}{l}\text { Tanggapan tentang gangguan dari kebisingan } \\
\text { yang ditimbulkan }\end{array}$ & $\begin{array}{c}\text { Frekuensi } \\
(\mathbf{F})\end{array}$ & $\begin{array}{c}\text { Persentase } \\
\left(\frac{\boldsymbol{F}}{\boldsymbol{N}} \mathbf{x} \mathbf{1 0 0 \%}\right)\end{array}$ \\
\hline \multirow{2}{*}{7} & Terganggu & 9 & 32,1 \\
\cline { 2 - 4 } & Tidak terganggu & 19 & 67,9 \\
\hline \multicolumn{2}{r}{ Total $(\mathbf{N})$} & $\mathbf{2 8}$ & $\mathbf{1 0 0 \%}$ \\
\hline
\end{tabular}

Sumber: Data Diolah (2018)

Terkait dengan pertanyaan yang diajukan, menunjukan sebanyak 9 informan menjawab kegiatan pertambangan nikel di Desa Roraya. Sementara 19 informan menjawab tidak. Hal ini menunjukan $32,1 \%$ informan menanggapi menimbulkan kebisingan atau gangguan bunyi.

Berdasarkan uraian diatas, dapat disimpulkan bahwa pertambangan nikel di Desa Roraya menimbulkan kebisingan tetapi masyarakat tidak tergganggu dengan kebisingan yang ditimbulkan dengan banyaknya tanggapan informan yakni $19(67,9 \%)$.

\begin{abstract}
Tanggapan masyarakat tentang pertambangan nikel mengganggu lahan pertanian

Untuk mengetahui tanggapan masyarakat tentang pertambangan nikel di Desa Roraya mengganggu lahan pertanian, maka diajukan pertanyaan: "Apakah lahan pertanian Bapak/ibu terganggu setelah masuknya pertambangan nikel di desa ini?". Tanggapan informan tentang terganggunya lahan persawahan akibat kegiatan pertambangan dapat dilihat pada tabel 4.8 .
\end{abstract}

Tabel 4.8. Tanggapan masyarakat tentang pertambangan nikel di Desa Roraya mengganggu lahan pertanian

\begin{tabular}{clcc}
\hline \multirow{2}{*}{ No } & $\begin{array}{l}\text { Tanggapan tentang gangguan lahan pertanian } \\
\text { oleh kegiatan pertambangan }\end{array}$ & $\begin{array}{c}\text { Frekuensi } \\
(\mathbf{F})\end{array}$ & $\begin{array}{c}\text { Persentase } \\
\left(\frac{\mathbf{F}}{\boldsymbol{N}} \mathbf{x} \mathbf{1 0 0 \%}\right)\end{array}$ \\
\hline \multirow{2}{*}{8} & Terganggu & 26 & 92,9 \\
\cline { 2 - 4 } & Tidak terganggu & 2 & 7,1 \\
\hline \multicolumn{2}{c}{ Total $(\mathbf{N})$} & $\mathbf{2 8}$ & $\mathbf{1 0 0 \%}$ \\
\hline
\end{tabular}

Sumber: Hasil Penelitian 2018

Terkait dengan pertanyaan yang diajukan, menunjukan sebanyak 26 informan menjawab bahwa kegiatan pertambangan mengganggu lahan 
pertanian. Sementara 2 informan menjawab tidak terganggu. Hal ini menunjukan $92,9 \%$ informan menanggapi kegiatan pertambangan nikel telah mengganggu lahan pertanian, karena ada beberapa lahan pertanian disekitar lokasi pertambangan tidak digarap lagi dan ditimbun untuk dijadikan lalu lintas alat pengangkut menuju pelabuhan.

Berdasarkan uraian diatas, dapat disimpulkan bahwa pertambangan nikel di Desa Roraya mengganggu lahan pertanian dengan banyaknya tanggapan informan yakni $26(92,9 \%)$.

\section{Dampak Terhadap Lingkungan Biologi}

\section{Tanggapan masyarakat tentang pertambangan nikel mengganggu/mengurangi areal perkebunan}

Untuk mengetahui tanggapan masyarakat tentang pertambangan nikel di Desa Roraya mengganggu/mengurangi areal perkebunan maka diajukan pertanyaan: "Apakah areal perkebunan Bapak/ibu terganggu/berkurang setelah masuknya pertambangan nikel di desa ini?". Tanggapan informan tentang terganggunya/berkurangnya areal perkebunan akibat kegiatan pertambangan dapat dilihat pada tabel 4.9 .

Tabel 4.9. Tanggapan masyarakat tentang pertambangan nikel di Desa Roraya mengganggu/mengurangi areal perkebunan

\begin{tabular}{clccc}
\hline \multirow{2}{*}{ No } & $\begin{array}{l}\text { Tanggapan tentang terganggunya } \\
\text { berkurangnya areal perkebunan oleh kegiatan } \\
\text { pertambangan }\end{array}$ & $\begin{array}{c}\text { Frekuensi } \\
(\mathbf{F})\end{array}$ & $\begin{array}{c}\text { Persentase } \\
\left(\frac{\boldsymbol{F}}{\boldsymbol{N}} \mathbf{x} \mathbf{1 0 0 \%}\right)\end{array}$ \\
\hline \multirow{2}{*}{9} & Terganggu/berkurang & 21 & 75 \\
\cline { 2 - 5 } & Tidak terganggu/berkurang & 6 & 21,4 \\
\cline { 2 - 5 } & Tidak tahu & 1 & 3,6 \\
\hline & Total $(\mathbf{N})$ & $\mathbf{2 8}$ & $\mathbf{1 0 0 \%}$ \\
\hline
\end{tabular}

Sumber: Hasil Penelitian 2018

Terkait dengan pertanyaan yang diajukan, menunjukan sebanyak 21 informan menjawab bahwa kegiatan pertambangan nikel di Desa Roraya, mengganggu/mengurangi areal perkebunan, sementara 6 informan menjawab tidak terganggu dan 1 informan menjawab tidak tahu. Hal ini menunjukkan $75 \%$ informan menanggapi bahwa perkebunan terganggu akibat adanya pertambangan nikel di Desa Roraya.

Berdasarkan uraian diatas, dapat disimpulkan bahwa pertambangan nikel di Desa Roraya mengganggu areal perkebunan dengan banyaknya tanggapan yakni informan $21(75 \%)$.
Tanggapan masyarakat tentang pertambangan nikel di Desa Roraya menimbulkan penuruan produktifitas pertanian/perkebunan

Untuk mengetahui tanggapan masyarakat tentang pertambangan nikel di Desa Roraya menimbulkan penurunan produktifitas pertanian/perkebunan, maka diajukan pertanyaan: "Apakah persawahan/perkebunan Bapak/ibu mengalami penurunan produktifitas setelah masuknya pertambangan nikel di desa ini?". Tanggapan informan tentang penurunan produktifitas pertanian/perkebunan sebagai akibat kegiatan pertambangan dapat dilihat pada tabel 4.10 . 
Jurnal Penelitian Pendidikan Geografi Volume 4 Nomor 1 Januari 2019

Tabel 4.10. Tanggapan masyarakat tentang pertambangan nikel di Desa Roraya menimbulkan penurunan produktifitas pertanian/perkebunan

\begin{tabular}{clcc}
\hline \multirow{2}{*}{ No } & $\begin{array}{l}\text { Tanggapan tentang penurunan produktifitas } \\
\text { pertanian/perkebunan }\end{array}$ & $\begin{array}{c}\text { Frekuensi } \\
(\mathbf{F})\end{array}$ & $\begin{array}{c}\text { Persentase } \\
\left(\frac{\boldsymbol{F}}{N} \mathbf{x} \mathbf{1 0 0 \%}\right)\end{array}$ \\
\hline \multirow{2}{*}{10} & Menurun & 22 & 78,6 \\
\cline { 2 - 4 } & Tidak menurun & 6 & 21,4 \\
\hline \multicolumn{2}{r}{ Total $(\mathbf{N})$} & $\mathbf{2 8}$ & $\mathbf{1 0 0 \%}$ \\
\hline
\end{tabular}

Sumber: Hasil Penelitian 2018

Terkait dengan pertanyaan yang diajukan, menunjukan sebanyak 22 informan menjawab bahwa kegiatan pertambangan nikel di Desa Roraya, menimbulkan penurunan produktifitas pertanian/perkebunan. Sementara 6 informan menjawab tidak. Hal ini menunjukan $78,6 \%$ informan menanggapi penurunan paling dirasakan pada saat musim hujan karena material dari pertambangan terbawa ke persawahan yang menyebabkan gagal panen.

Berdasarkan uraian diatas, dapat disimpulkan bahwa pertambangan nikel di Desa Roraya menimbulkan penurunan produktifitas pertanian/perkebunan dengan banyaknya tanggapan informan yakni $22(78,6 \%)$.

\section{Tanggapan masyarakat tentang pertambangan nikel di Desa Roraya menimbulkan kerusakan tumbuhan (flora)}

Untuk mengetahui tanggapan masyarakat tentang pertambangan nikel menimbulkan kerusakan tumbuhan (flora) maka diajukan pertanyaan: "Apakah Bapak/ibu menilai adanya kerusakan tumbuh-tumbuhan (flora) setelah masuknya penambangan nikel di desa ini?". Tanggapan informan tentang kerusakan tumbuhan (flora) akibat kegiatan pertambangan dapat dilihat pada tabel 4.11.

Tabel 4.11. Tanggapan masyarakat tentang pertambangan nikel di Desa Roraya menimbulkan kerusakan tumbuhan (flora)

\begin{tabular}{clcc}
\hline \multirow{2}{*}{ No } & $\begin{array}{l}\text { Tanggapan tentang kerusakan tumbuhan } \\
\text { (flora) }\end{array}$ & $\begin{array}{c}\text { Frekuensi } \\
(\mathbf{F})\end{array}$ & $\begin{array}{c}\text { Persentase } \\
\left(\frac{F}{N} \mathbf{x} \mathbf{1 0 0 \%}\right)\end{array}$ \\
\hline \multirow{2}{*}{11} & Menimbulkan kerusakan tumbuhan & 25 & 89,3 \\
\cline { 2 - 4 } & Tidak menimbulkan kerusakan tumbuhan & 3 & 10,7 \\
\hline \multicolumn{2}{c}{ Total (N) } & $\mathbf{2 8}$ & $\mathbf{1 0 0 \%}$ \\
\hline
\end{tabular}

Sumber: Hasil Penelitian 2018

Terkait dengan pertanyaan yang diajukan, menunjukan sebanyak 25 informan menjawab bahwa kegiatan pertambangan nikel di Desa Roraya, menimbulkan kerusakan tumbuhan (flora). Sementara 3 informan menjawab tidak. Hal ini menunjukan 89,3\% informan menilai hutan menjadi rusak karena pohon dan semak banyak yang digusur dengan alat-alat tambang untuk menggali biji nikel.

Berdasarkan uraian diatas, dapat disimpulkan bahwa pertambangan nikel di Desa Roraya menimbulkan kerusakan tumbuhan (flora) dengan banyaknya tanggapan informan yakni $25(89,3 \%)$. 


\begin{tabular}{|c|c|}
\hline $\begin{array}{l}\text { Tanggapan masyarakat tentang } \\
\text { pertambangan nikel di Desa Roraya } \\
\text { menimbulkan kerusakan hewan/satwa } \\
\text { liar (fauna) }\end{array}$ & $\begin{array}{l}\text { "Apakah Bapak/ibu menilai adanya } \\
\text { kerusakan atau menurunnya jumlah } \\
\text { satwa liar setelah masuknya } \\
\text { pertambangan nikel di desa ini?". }\end{array}$ \\
\hline Untuk mengetahui tanggapan & Tanggapan informan tentang kerusakan \\
\hline $\begin{array}{l}\text { masyarakat tentang pertambangan nikel } \\
\text { di Desa Roraya menimbulkan kerusakan }\end{array}$ & $\begin{array}{l}\text { atau menurunnya hewan atau satwa liar } \\
\text { (fauna) akibat kegiatan pertambangan }\end{array}$ \\
\hline
\end{tabular}
(fauna) maka diajukan pertanyaan:

Tabel 4.12. Tanggapan masyarakat tentang pertambangan nikel di Desa Roraya menimbulkan kerusakan atau menurunnya hewan/satwa liar (fauna)

\begin{tabular}{|c|c|c|c|}
\hline No & $\begin{array}{l}\text { Tanggapan tentang } \quad \text { kerusakan } \\
\text { menurunnya hewan/satwa liar (fauna) }\end{array}$ & $\begin{array}{l}\text { Frekuensi } \\
\quad(\text { F })\end{array}$ & $\begin{array}{l}\text { Persentase } \\
\left(\frac{F}{N} \times 100 \%\right)\end{array}$ \\
\hline \multirow{3}{*}{12} & $\begin{array}{l}\text { Menimbulkan kerusakan atau penurunan } \\
\text { hewan/satwa liar }\end{array}$ & 20 & 71,4 \\
\hline & $\begin{array}{l}\text { Tidak menimbulkan kerusakan atau penurunan } \\
\text { hewan/satwa liar }\end{array}$ & 8 & 28,6 \\
\hline & Total $(\mathbf{N})$ & 28 & $100 \%$ \\
\hline
\end{tabular}

Sumber: Hasil Penelitian 2018

Terkait dengan pertanyaan yang diajukan, menunjukan sebanyak 20 informan menjawab bahwa kegiatan pertambangan nikel di Desa Roraya, menimbulkan kerusakan dan penurunan hewan/satwa liar (fauna) Sementara 8 informan menjawab tidak. Hal ini menunjukan $71,4 \%$ informan menanggapi bahwa keadaan itu merupakan implikasi dari rusaknya hutan dan tumbuh-tumbuhan sehingga hewan yang ada di hutan mulai kehilangan habitatnya dan bermigrasi, bahkan punah.

Berdasarkan uraian diatas, dapat disimpulkan bahwa pertambangan nikel di Desa Roraya menimbulkan kerusakan atau penurunan hewan/satwa liar dengan banyaknya tanggapan informan yakni 20 $(71,4 \%)$.
Tanggapan masyarakat tentang adanya gangguan kesehatan ISPA, diare, batuk-batul, gatal-gatal sebagai dampak pertambangan nikel di Desa Roraya

Untuk mengetahui tanggapan masyarakat tentang gangguan kesehatan seperti ISPA, diare, batuk-batuk, gatalgatal sebagai akibat dampak pertambangan nikel di Desa Roraya, maka diajukan pertanyaan: "Apakah Bapak/ibu merasakan adanya gangguan kesehatan seperti ISPA, diare, batukbatuk, gatal-gatal setelah masuknya pertambangan nikel di desa ini?". Tanggapan informan tentang gangguan kesehatan sebagai akibat kegiatan pertambangan dapat dilihat pada tabel 4.13. 
Jurnal Penelitian Pendidikan Geografi Volume 4 Nomor 1 Januari 2019

Tabel 4.13. Tanggapan masyarakat tentang gangguan kesehatan seperti ISPA, diare, batuk-batuk, gatal-gatal sebagai akibat dampak pertambangan nikel di Desa Roraya

\begin{tabular}{clcc}
\hline \multirow{2}{*}{ No } & $\begin{array}{l}\text { Tanggapan tentang gangguan kesehatan } \\
\text { seperti ISPA, diare, batuk-batuk, gatal-gatal } \\
\text { akibat pertambangan }\end{array}$ & $\begin{array}{c}\text { Frekuensi } \\
(\mathbf{F})\end{array}$ & $\begin{array}{c}\text { Persentase } \\
\left(\frac{\boldsymbol{F}}{\boldsymbol{N}} \mathbf{x} \mathbf{1 0 0 \%}\right)\end{array}$ \\
\hline \multirow{2}{*}{13} & Mengalami gangguan kesehatan & 11 & 39,3 \\
\cline { 2 - 4 } & Tidak mengalami gangguan kesehatan & 17 & 60,7 \\
\hline \multirow{2}{*}{ Total (N) } & $\mathbf{2 8}$ & $\mathbf{1 0 0 \%}$ \\
\hline
\end{tabular}

Sumber: Hasil Penelitian 2018

Terkait dengan pertanyaan yang diajukan, menunjukan sebanyak 11 informan menjawab mengalami gangguan kesehatan sebagai akibat dampak pertambangan, sementara 17 informan menjawab tidak. Hal ini menunjukan $60,7 \%$ informan menilai adanya aktivitas tambang mereka tidak mengeluh/menderita penyakit tertentu,

Berdasarkan uraian diatas, dapat disimpulkan bahwa pertambangan nikel di Desa Roraya tidak menimbulkan gangguan kesehatan dengan banyaknya tanggapan informan yakni $17(60,7 \%)$.

\section{Dampak Terhadap Lingkungan Sosial}

Tanggapan masyarakat tentang pemberian pemberdayaan kesehatan oleh pihak pertambangan kepada masyarakat di Desa Roraya

Untuk mengetahui tanggapan tentang pemberian pemberdayaan kesehatan oleh pihak pertambangan kepada masyarakat, maka diajukan pertanyaan: "Apakah perusahaan memberikan pemberdayaan kesehatan kepada masyarakat di desa ini?" Tanggapan informan tentang pemberian pemberdayaan kesehatan oleh pihak pertambangan kepada masyarakat dapat dilihat pada tabel 4.14.

Tabel 4.14. Tanggapan masyarakat tentang pemberian pemberdayaan kesehatan oleh pihak pertambangan kepada masyaraka di Desa Roraya

\begin{tabular}{clccc}
\hline No & $\begin{array}{l}\text { Tanggapan tentang pemberian pemberdayaan } \\
\text { kesehatan }\end{array}$ & $\begin{array}{c}\text { Frekuensi } \\
(\mathbf{F})\end{array}$ & $\begin{array}{c}\text { Persentase } \\
\left(\frac{\boldsymbol{F}}{\boldsymbol{N}} \mathbf{x} \mathbf{1 0 0 \%}\right)\end{array}$ \\
\hline \multirow{2}{*}{14} & Ada & 7 & 25 \\
\cline { 2 - 5 } & Tidak ada & 21 & 75 \\
\hline & & $\mathbf{2 8}$ & $\mathbf{1 0 0 \%}$ \\
\hline
\end{tabular}

Sumber: Hasil Penelitian 2018

Terkait dengan pertanyaan yang diajukan, menunjukan sebanyak 7 informan menjawab ada pemberian pemberdayaan kesehatan yang dilakukan oleh pihak perusahaan kepada masyarakat di Desa Roraya, sementara 21 informan menjawab tidak ada. Hal ini menunjukan $75 \%$ informan menanggapi pemberdayaan yang dilakukan dibidang kesehatan dinilai tidak terealisasikan, kalau pun ada orang-orang tertentu saja yang dilayani.

Berdasarkan uraian diatas, dapat disimpulkan tidak ada pemberian pemberdayaan kesehatan yang dilakukan oleh pihak perusahaan kepada 
masyarakat di Desa Roraya dengan banyaknya tanggapan informan yakni 21 (75\%).

Tanggapan masyarakat tentang peningkatan prasarana kesehatan oleh pihak pertambangan kepada masyarakat di Desa Roraya

Untuk mengetahui tanggapan tentang peningkatan prasarana kesehatan oleh pihak pertambangan kepada masyarakat di Desa Roraya, maka diajukan pertanyaan: "Apakah Bapak/ibu merasa adanya peningkatan prasarana kesehatan di desa ini?" Tanggapan informan tentang peningkatan prasarana kesehatan oleh pihak pertambangan kepada masyaraka dapat dilihat pada tabel 4.15 .

Tabel 4.15. Tanggapan masyarakat tentang peningkatan prasarana kesehatan oleh pihak pertambangan kepada masyaraka di Desa Roraya

\begin{tabular}{lllcc}
\hline \multirow{2}{*}{ No } & $\begin{array}{l}\text { Tanggapan tentang peningkatan prasarana } \\
\text { kesehatan }\end{array}$ & $\begin{array}{c}\text { Frekuensi } \\
(\mathbf{F})\end{array}$ & $\begin{array}{c}\text { Persentase } \\
\left(\frac{F}{N} \mathbf{x} \mathbf{1 0 0 \%}\right)\end{array}$ \\
\hline \multirow{2}{*}{15} & Ada & 12 & 42,9 \\
\cline { 2 - 5 } & Tidak ada & 16 & 57,1 \\
\hline & & $\mathbf{2 8}$ & $\mathbf{1 0 0 \%}$ \\
\hline
\end{tabular}

Sumber: Hasil Penelitian 2018

Terkait dengan pertanyaan yang diajukan, menunjukan sebanyak 12 informan menjawab ada peningkatan prasarana kesehatan yang dilakukan oleh pihak perusahaan di Desa Roraya, sementara 16 informan menjawab tidak ada peningkatan prasarana kesehatan yang dilakukan oleh pihak perusahaan kepada masyarakat di Desa Roraya. Hal ini menunjukan $57,1 \%$ informan yang menjawab tidak karena mereka beranggapan bahwa prasarana kesehatan yang ada sudah seperti itu dari dulu, bahkan sebelum adanya pertambangan.

Berdasarkan uraian diatas, dapat disimpulkan tidak ada peningkatan prasarana kesehatan yang dilakukan oleh pihak perusahaan kepada masyarakat di
Desa Roraya dengan banyaknya tanggapan informan yakni $16(57,1 \%)$.

Tanggapan masyarakat tentang
peningkatan prasarana pendidikan
oleh pihak pertambangan di Desa
Roraya
Untuk mengetahui tanggapan
tentang peningkatan prasarana
pendidikan oleh pihak pertambangan di
Desa Roraya, maka diajukan pertanyaan:
"Apakah Bapak/ibu merasa adanya
peningkatan prasarana pendidikan di
desa ini?" Tanggapan informan tentang
peningkatan prasarana pendidikan oleh
pihak pertambangan dapat dilihat pada
tabel 4.16.

Tanggapan masyarakat tentang peningkatan prasarana pendidikan oleh pihak pertambangan di Desa Roraya

tentang peningkatan prasarana pendidikan oleh pihak pertambangan di Desa Roraya, maka diajukan pertanyaan: "Apakah Bapak/ibu merasa adanya peningkatan prasarana pendidikan di desa ini?" Tanggapan informan tentang peningkatan prasarana pendidikan oleh tabel 4.16 .

Tabel 4.16. Tanggapan masyarakat tentang peningkatan prasarana pendidikan oleh pihak pertambangan di Desa Roraya

\begin{tabular}{clccc}
\hline \multirow{2}{*}{ No } & $\begin{array}{l}\text { Tanggapan tentang peningkatan prasarana } \\
\text { pendidikan }\end{array}$ & $\begin{array}{c}\text { Frekuensi } \\
(\mathbf{F})\end{array}$ & $\begin{array}{c}\text { Persentase } \\
\left(\frac{\boldsymbol{F}}{N} \mathbf{x} \mathbf{1 0 0 \%}\right)\end{array}$ \\
\hline \multirow{2}{*}{16} & Ada & 23 & 82,1 \\
\cline { 2 - 5 } & Tidak ada & 5 & 17,9 \\
\hline \multicolumn{2}{r}{} & Total & $\mathbf{2 8}$ & $\mathbf{1 0 0 \%}$ \\
\hline
\end{tabular}

Sumber: Hasil Penelitian 2018 
Terkait dengan pertanyaan yang diajukan, menunjukan sebanyak 23 informan menjawab ada peningkatan prasarana pendidikan ,sementara 5 informan menjawab tidak. Hal ini menunjukan $82,1 \%$ informan menanggapi bahwa pihak perusahaan memberikan kontribusi yang cukup besar di bidang pendidikan kepada sekolahsekolah di Desa Roraya seperti pengadaan kelengkapan tulis menulis, buku-buku bacaan, beasiswa tidak mampun dan sebagainya.

Berdasarkan uraian diatas, dapat disimpulkan bahwa ada peningkatan prasarana pendidikan yang dilakukan oleh pihak perusahaan kepada masyarakat dengan banyaknya tanggapan informan yakni $23(82,1 \%)$.

\section{Tanggapan masyarakat tentang peluang kesempatan kerja di Desa Roraya}

Untuk mengetahui tanggapan masyarakat tentang peluang kesempatan kerja di Desa Roraya, maka diajukan pertanyaan: "Apakah Bapak/ibu menilai usaha pertambangan nikel membuka kesempatan kerja yang cukup besar di desa ini?" Tanggapan informan tentang peluang kesempatan kerja dapat dilihat pada tabel 4.17.

Tabel 4.17. Tanggapan masyarakat tentang peluang kesempatan kerja di Desa Roraya

\begin{tabular}{clcc}
\hline \multirow{2}{*}{ No } & Tanggapan tentang peluang kesempatan kerja & $\begin{array}{c}\text { Frekuensi } \\
(\mathbf{F})\end{array}$ & $\begin{array}{c}\text { Persentase } \\
(-\mathrm{F} \mathbf{x} \mathbf{1 0 0 \%})\end{array}$ \\
\hline \multirow{2}{*}{17} & Peluang kerja cukup besar & 21 & 75 \\
\cline { 2 - 4 } & Tidak juga & 7 & 25 \\
\hline \multicolumn{2}{c}{ Total $(\mathbf{N})$} & $\mathbf{2 8}$ & $\mathbf{1 0 0 \%}$ \\
\hline
\end{tabular}

Sumber: Hasil Penelitian 2018

Terkait dengan pertanyaan yang diajukan, menunjukan sebanyak 21 informan menjawab ada peluang kesempatan kerja yang cukup besar di Desa Roraya, sementara 7 informan menjawab tidak juga. Hal ini menunjukan $75 \%$ informan merasakan masuknya pertambangan nikel membuka kesempatan kerja yang cukup besar bagi warga desa walaupun hanya pekerja buruh.

Berdasarkan uraian diatas, dapat disimpulkan bahwa peluang kesempatan kerja di Desa Roraya cukup besar dengan banyaknya tanggapan informan yakni 21 (75\%).

\begin{abstract}
Tanggapan masyarakat tentang tercukupnya kebutuhan sehari-hari setelah adanya tambang di Desa Roraya

Untuk mengetahui tanggapan masyarakat tentang tercukupnya kebutuhan sehari-hari setelah adanya pertambangan nikel, maka diajukan pertanyaan: "Apakah Bapak/ibu dapat mencukupi kebutuhan sehari-hari setelah adanya pertambangan nikel di desa ini?" Tanggapan informan tentang tercukupnya kebutuhan sehari-hari setelah adanya pertambangan dapat dilihat pada tabel 4.18 .
\end{abstract}


Tabel 4.18. Tanggapan masyarakat tentang tercukupnya kebutuhan sehari-hari setelah adanya pertambangan nikel di Desa Roraya

\begin{tabular}{clccc}
\hline \multirow{2}{*}{ No } & $\begin{array}{l}\text { Tanggapan tentang tecukupnya kebutuhan } \\
\text { sehari-hari setelah adanya pertambangan }\end{array}$ & $\begin{array}{c}\text { Frekuensi } \\
(\mathbf{F})\end{array}$ & $\begin{array}{c}\text { Persentase } \\
\left(\frac{\boldsymbol{F}}{N} \mathbf{x} \mathbf{1 0 0 \%}\right)\end{array}$ \\
\hline \multirow{2}{*}{18} & Tercukupi & 15 & 53,4 \\
\cline { 2 - 4 } & Tidak tercukupi & 13 & 46,6 \\
\hline \multicolumn{2}{c}{ Total $(\mathbf{N})$} & $\mathbf{2 8}$ & $\mathbf{1 0 0 \%}$ \\
\hline
\end{tabular}

Sumber: Hasil Penelitian 2018

Terkait dengan pertanyaan yang diajukan, menunjukan sebanyak 15 informan menjawab dapat mencukupi kebutuhan sehari-hari setelah adanya pertambangan, sementara 13 informan menjawab tidak. Hal ini menunjukan $53,4 \%$ informan menanggapi kebutuhan sehari-hari lebih tercukupi sejak adanya pertambangan. Namun ini berlaku bagi mereka yang bekerja di pertambangan.

Berdasarkan uraian diatas, dapat disimpulkan bahwa peluang kesempatan kerja di Desa Roraya cukup besar dengan banyaknya tanggapan informan yakni 15 $(53,4 \%)$

\begin{abstract}
Tanggapan masyarakat tentang perubahan prilaku/norma masyarakat sebagai dampak pertambangan nikel di Desa Roraya Untuk mengetahui tanggapan masyarakat tentang perubahan perilaku/norma masyarakat sebagai dampak pertambangan nikel di Desa Roraya, maka diajukan pertanyaan: "Apakah Bapak/ibu menilai bahwa masuknya pertambangan nikel di desa ini telah menimbulkan perubahan prilaku atau norma masyarakat?" Tanggapan informan tentang perubahan prilaku/norma masyarakat sebagai akibat kegiatan pertambangan dapat dilihat pada tabel 4.19.
\end{abstract}

Tabel 4.19. Tanggapan masyarakat tentang perubahan prilaku/norma masyarakat sebagai akibat dampak pertambangan nikel di Desa Roraya

\begin{tabular}{|c|c|c|c|c|}
\hline No & $\begin{array}{l}\text { Tanggapan } \\
\text { prilaku/norma } \\
\text { pertambangan }\end{array}$ & $\begin{array}{cr}\text { tentang } & \text { perubahan } \\
\text { masyarakat } & \text { akibat }\end{array}$ & $\begin{array}{l}\text { Frekuensi } \\
\text { (F) }\end{array}$ & $\begin{array}{l}\text { Persentase } \\
\left(\frac{F}{N} \times 100 \%\right)\end{array}$ \\
\hline \multirow[b]{2}{*}{19} & \multicolumn{2}{|c|}{ Terjadi perubahan prilaku/norma masyarakat } & 18 & 64,3 \\
\hline & $\begin{array}{l}\text { Tidak terjadi } \\
\text { masyarakat }\end{array}$ & perubahan prilaku/norma & 10 & 35,7 \\
\hline & & $(\mathrm{N})$ & 28 & $100 \%$ \\
\hline
\end{tabular}

Sumber: Hasil Penelitian 2018

Terkait dengan pertanyaan yang diajukan, menunjukan sebanyak 18 informan menjawab terjadi perubahan prilaku/norma masyarakat sebagai akibat dampak pertambangan, sementara 10 informan menjawab tidak. Hal ini menunjukan $64,3 \% \quad$ informan menanggapi bahwa penduduk desa mulai mengalami perubahan prilaku/norma,terutama dikalangan anak muda seperti miras, berjudi, iri hati, dan sikap sombong dalam perektrutan karyawan.

Berdasarkan uraian diatas, dapat disimpulkan bahwa terjadi perubahan prilaku/norma masyarakat di Desa Roraya sebagai akibat dampak 
pertambangan dengan banyaknya tanggapan informan yaitu 18 (64,3\%).

Kesetujuan masyarakat tentang kerjasama antara masyarakat, pemerintah, dan pengelolah tambang untuk menanggulangi kerusakan lingkungan akibat pertambangan nikel di Desa Roraya

Untuk mengetahui tanggapan masyarakat tentang kerjasama masyarakat, pemerintah dan pengelolah tambang untuk menanggulangi kerusakan lingkungan akibat dampak pertambangan nikel di Desa Roraya, maka diajukan pertanyaan: "Apakah Bapak/ibu setuju jika antara masyarakat, pemerintah dan pengelolah tambang saling bekerjasama untuk menanggulangi kerusakan lingkungan akibat pertambangan nikel di desa ini?" Tanggapan informan mengenai kerjasama masyarakat, pemerintah dan pengelolah tambang untuk menanggulangi kerusakan lingkungan akibat dampak pertambangan nikel dapat dilihat pada tabel 4.20.

Tabel 4.20. Tanggapan masyarakat tentang kerjasama masyarakat, pemerintah dan pengelolah tambang untuk menanggulangi kerusakan lingkungan akibat dampak

pertambangan nikel di Desa Roraya

\begin{tabular}{clcc}
\hline \multirow{2}{*}{ No } & $\begin{array}{l}\text { Tanggapan tentang kerjasama masyarakat, } \\
\text { pemerintah dan pengelolah tambang untuk } \\
\text { menanggulangi kerusakan lingkungan }\end{array}$ & $\begin{array}{c}\text { Frekuensi } \\
(\mathbf{F})\end{array}$ & $\begin{array}{c}\text { Persentase } \\
\left(\frac{\boldsymbol{F}}{N} \mathbf{x} \mathbf{1 0 0 \%}\right)\end{array}$ \\
\hline \multirow{2}{*}{20} & Setuju & 28 & 100 \\
\cline { 2 - 4 } & Tidak setuju & 0 & 0 \\
\hline \multirow{2}{*}{ Total $(\mathbf{N})$} & $\mathbf{2 8}$ & $\mathbf{1 0 0 \%}$ \\
\hline
\end{tabular}

Sumber: Hasil Penelitian 2018

Terkait dengan pertanyaan yang diajukan, menunjukan Masyarakat merespon dengan sangat terbuka bahwa mereka setuju jika antara masyarakat, pemerintah dan pengelolah tambang saling bekerjasama dalam mengatasi kerusakan lingkungan di Desa Roraya.

\section{PEMBAHASAN}

Disamping meningkatkan PAD dan membuka peluang usaha baru, keberadaan pertambangan nikel juga dirasakan masih kurang oleh masyarakat terutama dalam perkrutan karyawan, pengawasan kesehatan, bahkan sering terjadi konflik antara masyarakat dengan perusahaan pertambangan dalam hal pembebasan lahan, kerusakan lingkungan dan juga limbah dari perusahan yang berdampak pada lingkungan hidup yang ada di sekitar lokasi pertambangan.
Sebagai perusahaan yang aktivitasnya sangat dekat dengan masyarakat, maka haruslah memiliki program Corporate Sosial Responsibility (CSR). Corporate Sosial Responsibility (CSR) merupakan komitmen perusahaan untuk membangun kualitas kehidupan yang lebih baik bersama dengan pihak yang terkait, utamanya masyarakat disekelilingnya dan lingkungan dimana perusahaan tersebut berada, yang dilakukan terpadu dengan kegiatan usahanya secara berkelanjutan.kasi pertambangan.

\section{PENUTUP}

\section{a. Kesimpulan}

Berdasarkan pembahasan hasil penelitian di atas, maka dapat disimpulkan sebagai berikut

1. Kegiatan pertambangan nikel memiliki dampak positif, seperti : 
bertambahnya PAD dari sector pertambangan, terciptanya lapangan pekerjaan, serta terbukanya wilayah dari keterisolasian.

2. Kegiatan pertambangan nikel memiliki dampak negatif. Seperti terjadinya kerusakan lingkungan hidup, antara lain: 1) Kerusakan jalan; 2) Air sungai dan kali menjadi kabur dan berwarna serta kotor; 3)Polusi udara; 4) Kerusakan lahan; 5) Kerusakan flora dan fauna; 6) Tidak adanya pemberdayaan kesehatan kepada masyarakat; 7) Perubahan perilaku masyarakat.

\section{b. Saran}

Berdasarkan hasil penelitian diatas maka peneliti menyarankan agar pemerintah, khususnya Dinas Pertambangan dan Badan Lingkungan Hidup (BLH) dan pengelola tambang, untuk lebih mengutaman proses AMDAL serta lebih meningkatkan pengawasan dan evaluasi terhadap aktivitas pertambangan agar tidak menimbulkan kerusakan komponen lingkungan hidup serta dan berkelanjutan.

\section{DAFTAR PUSTAKA}

Dyahwati, Dewi. 2007. Ekonomi Versus Lingkungan. Jakarta: Bumi Aksara.

Kuswardoyo. 2009. Panduan Belajar Geografi: Untuk SMA \& MA Kelas XI. Jakarta: Pusat Perbukuan, Departemen Pendidikan Nasional.

Mukhtar dan Erna, Widodo. 2000. Konstruksi kearah Penelitian Deskriptif. Jakarta: Avyrous.
Rissamasu, Frida, Dkk. 2010. Jurnal: Pengelolaan penambangan bahan galian Golongan C Di Kabupaten Merauke. Diakses : 15 Februari 2018

Pemerintah Kabupaten. 2011. Badan Pusat Statistik Sulawesi Tenggara.

Pemerintah Kabupaten. 2017. Statistik Daerah Kabupaten Konawe Selatan.

Undang-Undang Nomor 32 Tahun 2009 tentang Pengelolaan dan Perlindungan Lingkungan Hidup. 